Tatiana G. Malinina

doctor of arts, professor, chief researcher of the Research Institute of Theory and History

of Fine Arts at the Russian Academy of Arts e-mail: tgmal01@yandex.ru

Russia, Moscow

ORCID 0000-0003-0785-305X

DOI: 10.36340/2071-6818-2019-15-3-139-168

\title{
Iconology and Methods of Studying Artistic Processes of the Modernism Era. Commentary on Mikhail Sokolov's Article «Iconology and the Study of Soviet Art. On the Problem of Hidden Symbolism ${ }^{1}$
}

Annotation: the proposed article develops the summarized report presented by the author at the conference of the Research Institute of Theory and History of Fine Arts of the Russian Academy of Arts "Image and Plot in Visual Arts. Poetics from Antiquity to Modern Times" (X.2018) dedicated to the memory of Mikhail Nikolaevich Sokolov who was a consistent and talented successor of the interpretation strategies of Erwin Panofsky's iconological method. The author refers to a little-known article by a remarkable scientist published in one of the reprint collections of the Research Institute of the Russian Academy of Arts (1991). Sokolov's reflections on the problems of methodology, the use of iconological analysis connected to the study of the art of modern and contemporary times, in particular, the art of social modernism, bring into focus the content of his article. Special tools are needed to answer the question on what the spiritual world of a man of the twentieth century was, how the tragic events of the century were reflected in it. The tools the researcher used relatively recently to study the artist's relations with society, the social order, the political system, the dictate of power and its order cannot contribute to solving new issues arising today. Therefore, the need to find (to develop) a method of extracting the desired knowledge in the spiritual life of the artist of the modernist era is the prerogative. The published article is a reflection and a kind of commentary on the methodological strategies proposed by Sokolov. The correlation of his own experience of many years of work on the study of the artistic creativity of the modernist era serves as an additional argument in favour of the applicability and effectiveness of the iconological method.

1. Sokolov M.N. "Iconology and the Study of Soviet art - on the Problem of Hidden Symbolism”. Pp.198-216 // Style. Image. Time. Moscow: SRI RAX, 1991. 
There is a three-part article structure. The first part deals with the aspects of Sokolov's article. The second and third parts of the article are devoted to the iconological analysis of the works of two painters (St. Petersburg-Leningrad): the landscapes by Nikolai Protopopov (1876-1960) and the still lifes of his wife Elizabeth Uvodskaya (1875-1943). The iconological analysis of N. Protopopov's works shows the presence of semantic subtexts, symbolic content, indicating a clear difference between the artist's values and the stilted rhetoric of the semiofficial narrative in relation to the events. The creative work of his wife, artist Elizabeth Vladimirovna Uvodskaya, appears to be completely unresearched due to particular life circumstances: the works were lost in the flow of events of the First World War and the revolution, absorbed by the spontaneous market of the the New Economic Policy (NEP) period and lost in the post-war years. The documents, letters, diaries were used for the kindling the stove in besieged Leningrad. Elizaveta Vladimirovna died during the blockade in 1943. The artist's analyzed still lifes are being published for the first time. The iconological method of understanding the cultural meanings and deciphering symbols helps to reveal the affirmation of another reality in the structure of the works of both artists, in their style, semantics and symbolism.

Keywords: methodological arsenal of contemporary art history, methods for analyzing the art of the $20^{\text {th }}-21^{\text {st }}$ centuries, Mikhail Sokolov on the use of the iconological method in studies of the art of the Soviet period, the principle of hidden symbolism in Erwin Panofsky's theory, examples of iconological analysis.

\footnotetext{
“... each individual has within himself his own aims and yet has them to serve a general purpose incomprehensible to man "

War and Peace. Epilogue. Leo Tolstoy
}

In an effort to replenish the methodological arsenal of contemporary art history, theorists corroborate the synthetic principle combining analytical techniques of the formal and stylistic, cultural, structuralist, deconstructivist and other methods. Modern science comes to the conclusion that it is possible to extend the methods of analysis, used by their founders only in the framework of the studied periods of antiquity and the Middle Ages or the Renaissance and Baroque, to the art of the 20th and early 21 st centuries. In one of his articles ${ }^{2}$, Sokolov, in particular, noted that if E. Panofsky himself was quite skeptical about the possibility of an iconological view on the art of the 19th-20th centuries. Though, it would seem that during this time the iconographic canons disappeared from the scene, giving way to more or less free artistic choice of themes and images. However, modern

2. 2 loc. cit. P.199 


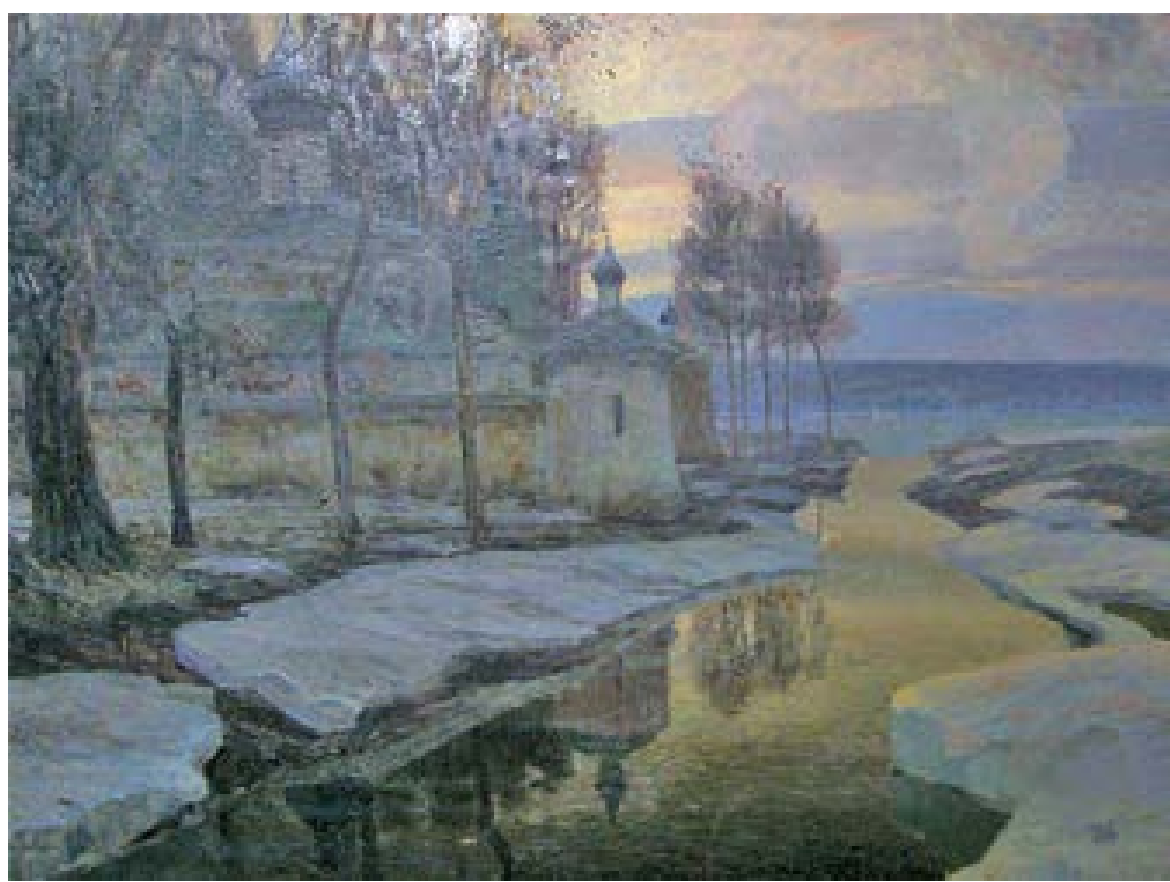

Protopopov N. The Dusk. Oil on canvas, 1900. BGHM. Ufa.

scholars came to the opposite conclusion, arguing that a stable plot and thematic typology as well as strictly defined symbolic structures turn out to be just as characteristic not only for ancient but for modern and contemporary aesthetic thinking. [1. Pp.199-200]

As a valuable additional argument in favour of the use of the iconological method for the study of contemporary art, Sokolov suggested the principle of hidden symbolism. According to his words, the principle, originally identified by E. Panofsky and K. Tolnay on the basis of Dutch painting during the late Middle Ages, implies an organic coexistence of medieval symbolism and the Renaissance mimesis within the same image. Medieval aesthetics constructed a world of symbols openly violating the empirical skills of visual perception. The allegorical meaning in itself was not masked, but clear, existing as if parallely to the artistic form. Just as in theological exercises for studying the Holy Writ, the text was invariably followed by the question: "How is this to be understood spiritually?". Panofsky claims that the principle of hidden symbolism begins to operate from the moment the space of the picture begins to follow the laws of empirical space so the artist has to hide the theological and symbolic meanings, which his predecessors demonstrated openly, under the cover of external plausibility ${ }^{3}$. [2.

3. Panofsky E. Renaissance and Renasences in Western Art. Stockholm, 1960. P.141-142. 
Pp.141-142]. By analogy with the integrity achieved by a strong union of the early realistic method and metaphorical conventionality, M. Alpatov, describing similar phenomena, introduced the term realistic symbols [4. P.153]. Commenting on this procedure of thinking, M. Sokolov emphasizes the fallacy of the inveterate prejudice of contrasting the "symbolic" Middle Ages to the "realistic" modern times, which are essentially supposedly hostile to the conventionally metaphorical view of the world. Interpreting the symbolism of the Middle Ages as the antithesis of the realism of the Renaissance, the prevailing stereotype turned out to be very common in the study of art of our century. Nowadays symbolic modernism is artificially opposed to realism, to the more traditional forms of artistic vision where metaphors, if they exist, are supposedly of a purely secondary role. "The abundance of allegories is characteristic of all stages of the development of modernist aesthetics from Art Nouveau to surrealism and to the later ones," he notes. "Often, successive stages of the appearance or masking of a symbol are most directly included in the artistic substance, as, for example, in the early V. Kandinsky's non-objective compositions in which pictorial signs (a boat, church domes, a mountain, horsemen, etc.) seem to emerge out of the elements of abstract forms for some time, hiding in them afterwards $\rangle^{4}$. [1. P.204]

The iconological analysis done by the researcher in the mentioned article is aimed at the specifics of the figurative perception of the art of the 1920s 1930s by his contemporaries [12. Pp.204-211; 13. Pp.61-69]. Evaluating this experience, the author notes that a net of various associations between works is revealed as a result of the analysis. In many cases, various crypto-iconographic art variations help to clarify the connection between an image and the era with special clarity even making it possible to predict not only aesthetic sympathies, but also a reaction to changes in socio-political climate of the time. The author also claims that the iconological analysis is applicable to any artistic phenomenon of modernism, including the art of social modernism, bearing in mind not only the material of the two decades highlighted in the article, but also the first postwar years, the Thaw, the Era of Stagnation. A lot of diverse examples of cryptoiconography may be found researching these periods.

In conclusion, in an in-depth study of this phenomenon, the author advises the interested reader to remember Pascal's Wager which advises not to make two mistakes. Firstly, do not perceive everything literally, and secondly, do not perceive everything spiritually (i.e. allegorically). "Avoiding these extremes," he summarizes, "art history can open up many new unexpected facets of both Russian and foreign culture of modern and contemporary times by combining an understanding of external historical and stylistic circumstances with understanding symbolic perspective" ${ }^{\text {. }}$. [1. P.214]

4. loc. cit. P.204.

5. loc. cit. P.214. 
Sokolov's research field includes not only independent social observations of the artist, but also an interest in religious subjects and symbols. And, indeed, today, anyone who is exploring the art of the era of modernism is faced with the need to unravel the visual ciphers associated with religious symbolism.

I will give examples from my own experience, in particular, from the research of the creative work of Nikolai Adrianovich Protopopov ${ }^{6}$, a little-known St. Petersburg painter [5. Pp.94-110], and his wife Elizabeth Vladimirovna Uvodskaya.

They were peers. They both devoted their lives to one profession, both received a spiritual and secular education, both were established individuals when the revolution began. Nevertheless, each of them was going one's own creative way, and their voices are distinguishable in historical time.

Nikolai Protopopov spent his childhood and youth in Birsk where his father served as a senior deacon. He graduated from a parish school in Birsk and after from a theological school and seminary in Ufa. Subsequently, he entered the Kazan Theological Academy and concurrently began to attend classes at the Kazan Art School from the second year. After completing his studies at the Theological Academy, he studied for three years at an art school which he graduated with the right to enter the Higher Art School of the Imperial Academy of Arts in 1903. In 1912, he was received the title of artist for the painting After a Stormy Night (oil on canvas, $2.5 \times 3$; N. Dubovsky's workshop). He lost his job. We find about it only from the notes from The World of Art Magazine and childhood memories of the artist's grandchildren. However, even from the verbal description, it seems that the author enriched N. Ge's tradition of apocryphal painting with the colouristic and allegorical figurative esotericism of the symbolism. The thesis was awarded with the Ivan Ivanovich Endogurov Prize given for the best landscape.

The understanding of the style and imaginative possibilities of the modern landscape was formed by the artist during trips to Paris, London, Venice and Munich. He was attracted to the language of late Impressionist painting, deeply interested in the art of the Pre-Raphaelites, shows interest in the late Renaissance and mannerism, as well as in German art of the turn of the century. The understanding of different languages of painting, different views on the world, refracted in the artist's mind, helped him bring the high and spiritualize the close. This synthesis promised the appearance of a qualitatively new imagery and style, rich opportunities for their understanding in different interpretations of the landscape genre. According to the artist, the Russian interpretation of the new imagery should have been based on the ideas of Nesterov and Levitan, while avoiding literature. The search for ways to embody the idea of a landscape painting, the transition from a sketch to a large canvas is noted in the artist's

6. Malinina T. "Artist N.Protopopov and his Family. Experience in Biographical Research." Pp.94-110 // The Study of a Scientist. Scientific articles, publications, essays. Moscow: Progress-Tradition, 2006. 


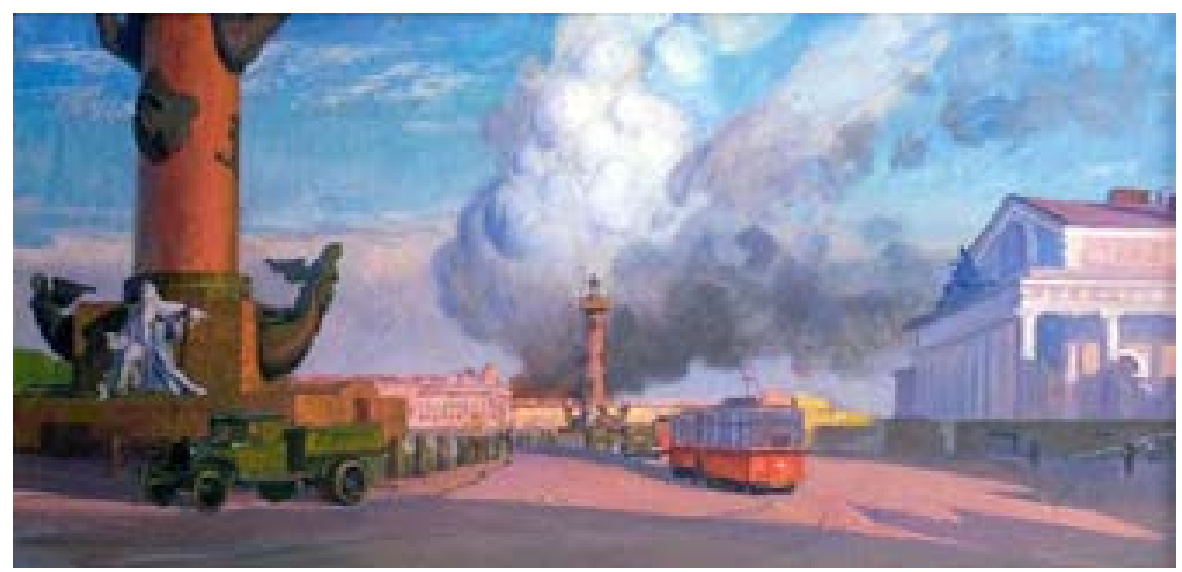

Protopopov N. The Fire. Oil on canvas, 1942. Russian Museum. SPb.

work starting from the 1910s. In the future, until the mid-1920s, the artist's creative work would feel the tension of the internal dialogue of the eternal with the momentary. Protopopov's imaginative transformations present in his sketches and paintings could be judged by his many works on the theme "Nature as a Temple". It is no accident that the artist, as a rule, presented an etude and a picture on the same topic at the exhibition (for example, Mirozhsky Monastery is the most famous work). The large canvas of 1917, called High Water, with its endless gray sky on a cloudy day, deformed blocks of ice floating on the river, inspired by vague foreboding of great change, signify a decisive turn in the artist's creative work to hidden symbolization of images. The ideas developed by the experience of direct communication with nature, the ideas perceived from modernist aesthetics were refracted in their own way and, in the end, were ready to result in powerful synthetic images, turned out to be dissolved and strictly dosed in the works of the 1930s. The reasons are clear, and we will leave them outside the scope of the narrative. It is important to see how the ideal of the artist is now embodied, where he finds meaning and comfort, if there is something in his works that was prompted by a desire to express disagreement, to object, to confront external circumstances. The artist does not have this; however, there is a clear, uncomplicated view of the world also inherent in the mood and mild intonation of the works of the writers M. Prishvin and I. Shmelev, artists V. Favorsky and the Chernyshov brothers. In their works, the world of God is great, diverse, and its beauty is manifested everywhere.

The extension of the thematic range of landscapes, characteristic of easel painting of the 1930s, is also manifested in the work of Nikolai Adrianovich Protopopov. However, the conformity with the official order ends with the concurrence with the general tendency to deepen the content of the work [16. P.73-93] due to the fact that a discrepancy in understanding the meaning of this 


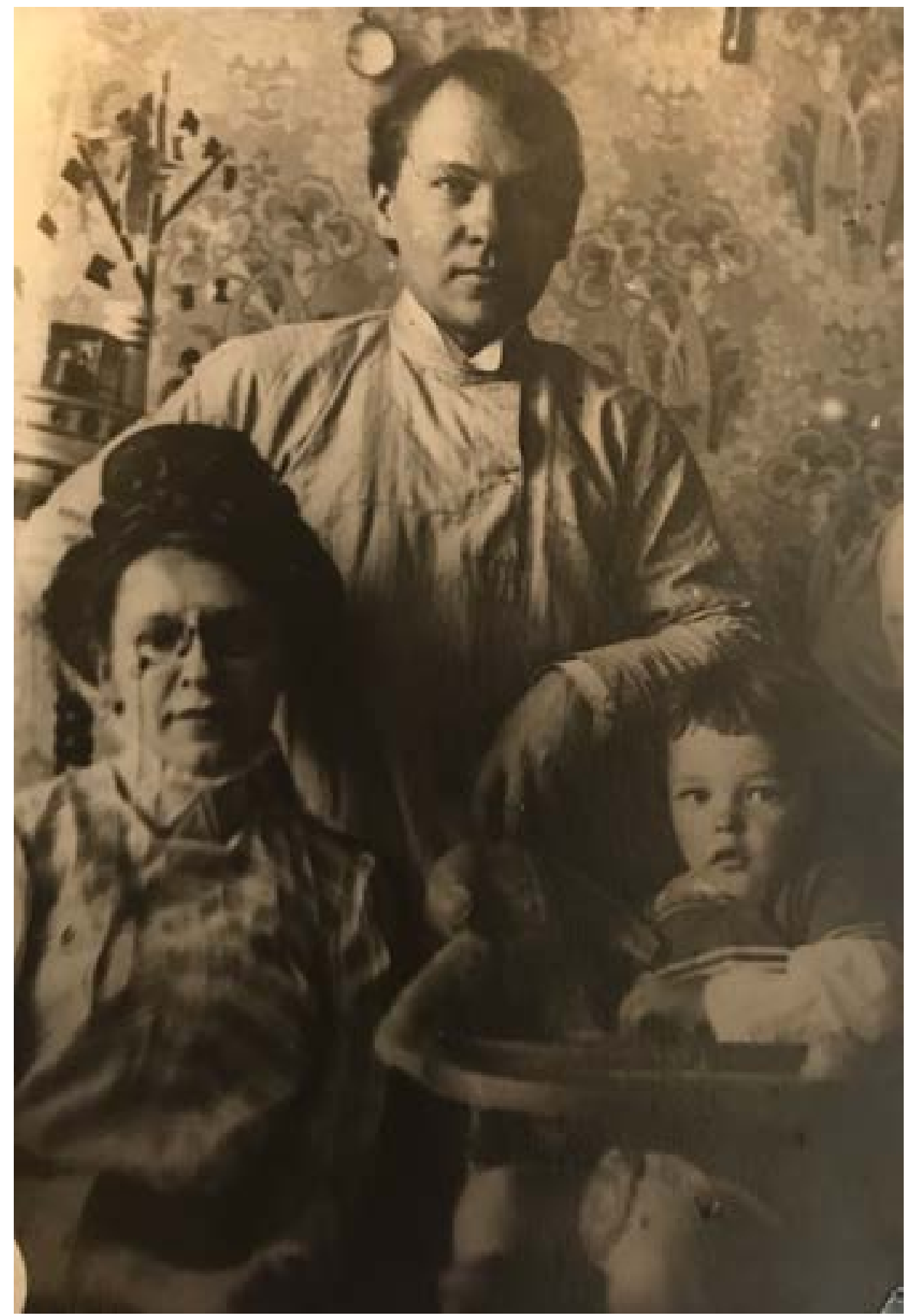

Uvodskaya E. With Husband and Son Anatoly. 1909 
depth appeared. It seems that allusions are replaced easily, without much effort in the artist's allegorical and poetic interpretation of the plot. The painter's works are devoid of pathos rhetoric, his look is attentive and focused, and landscapes, including architectural motifs, elements of genre or subject-themed painting, are in the nature of the biblical narrative. In them, nature appears in an amazing way combining dignity and silent sympathy. What is going on there looks like a leisurely ritual action. Fishing (Fish of Lake Imandra, A Big Catch, Unloading of Ships on the Northern River) or spring plowing (Spring) are depicted as eternal, God-established order for man. In understanding the foundations of being, embodied in the works of the painter, the idea of hidden God is an important part of the authenticity of the imaginable and visible images. The viewer notices it owing to the mobility and transparency of the very structure of the image, its diversity and vagueness as symbols of time in the artist's creative work. It was these qualities which made N. Protopopov a second-row artist in the eyes of critics of those years requiring greater specificity and certainty in expressing the connection with the era. Thus, in these historical circumstances, the painter's seemingly unrealizable dream of a landscape painting of deep philosophical content is nevertheless realized in the stated above thematic paintings of the prewar period, as well as in the works of the war years, indicating the possibility of preserving spiritual sovereignty from ideological dictatorship.

In 1942, N. Protopopov painted The Fire ${ }^{7}$, stored nowadays in the Russian Museum [6. Catalog]. Although many full-scale sketches were made by artists and architects of the besieged city, they remained genre works for the most part during the terrible blockade fires when warehouses with food, combustible materials and ammunition, shipyards, depots, factories, which had served as the basis for a large number of easel works, burned. Protopopov created an epic canvas, showing that he had mastered the secret of transforming pictorial matter from a visible image into an image-symbol. A huge cloud hanging over the city becomes a harbinger of great misfortune and difficult trials. At the same time, the panorama opening from the "arrow" of Vasilyevsky Island is so beautiful, the blue of the sky is so dazzling that it seems as if the city exists in another dimension, in the highlands, while remaining unapproachable, inaccessible to the forces of destruction. The impending catastrophe is met with dignity, meekness and hope. Iconological analysis shows the presence of semantic subtexts, symbolic content, indicating a clear discrepancy between the artist's values and the stilted rhetoric of an officious narrative in relation to current events. In other words, the symbolization of the images of the war years art is inspired by impulses of independent thinking of a personal character. At this moment, the strength of the human spirit brought to life the deepest existential meanings, basically timeless [7].

7. Exhibition of Artist N. Protopopov's Works. Catalog. Lenizo, 1951. 
The creative work of the artist's wife, Elizabeth Vladimirovna Uvodskaya, is completely unexplored owing to special life circumstances. The works were lost in the stream of events of the First World War and the Revolution, absorbed by the spontaneous market of NEP and lost in the post-war years, whereas documents, letters, diaries were used for kindling the stove in besieged Leningrad. Elizaveta Vladimirovna died during the blockade in 1943.

When in the early 2000s I was doing research for an article on N. Protopopov, important information on Uvodskaya's biography, in particular, the time and place of her birth, was discovered in the archives of the Russian Academy of Arts and the Russian State Archive of St. Petersburg. Elizabeth Belyaeva (nee Uvodskaya) was born in the family of a priest in Bogorodskoye village in the Ufa district on April 2, 1875. In M. Nesterov's book Long Days we find mention of this village. The artist tells that the Shihan mountain on the banks of the Belaya River was the favourite place for Ufa youth to go for a walk. "From here, Bogorodskoye village can be seen: a monastery is just around the corner. What limitless expanse is visible from there! The foothills of the Urals begin there, and such a sweet longing seizes you when looking at these alluring distances!"

The following information is contained in the case of a student of the Higher School of Arts under the Imperial Academy of Arts. On September 3, 1890, the daughter of Archpriest Vladimir Vasilievich Uvodsky and his wife Pulcheria Arkadevna, the damsel Elizaveta Uvodskaya, 17 years old, was accepted as a student of the Ufa Diocesan Women's School, the full course of which she graduated in 1893 with the right to the title of a home teacher [8. Fund 789. F. 12.1903].

Over the next ten years, Elizaveta Uvodskaya studied at the Kazan Art School and at the Odessa Art School. The fact that the future artist was studying at the Odessa Art College was recently found out from D. Burliuk's memoirs published in 1988: "1900/01... Of those who studied with me, I remember by the names of Peter Maksimovich Dulsky, Ivanovskaya, Germogen Tsitovich - grandson of Aksakov, a very gifted person who was prevented from becoming a good Cézannist by war and extraordinary scrupulosity. I also remember Uvodskaya,

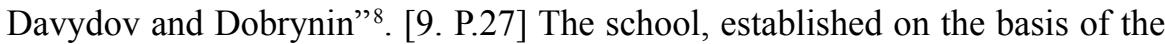
Drawing School of the Odessa Society of Fine Arts in 1900, was popular among artists and gained a solid reputation as an educational institution. Its graduates received the right to the title of teachers of painting and drawing in secondary schools and preferential admission to the Imperial Academy of Arts ${ }^{9}$. [10. P.133]. After graduating in 1903, Elizaveta Uvodskaya was admitted to the Higher Art

\footnotetext{
Burliuk D. "Memoirs of the Father of Russian Futurism." P.27 // The Past. Historical almanac. 5. Copyright by Atheneum, 1988. Paris.

9. Barkovskaya O. "Odessa Art School. Chronicle of 1865-1940." P.133 // News of the Odessa Art Museum. 2. Odessa, 2015.
} 


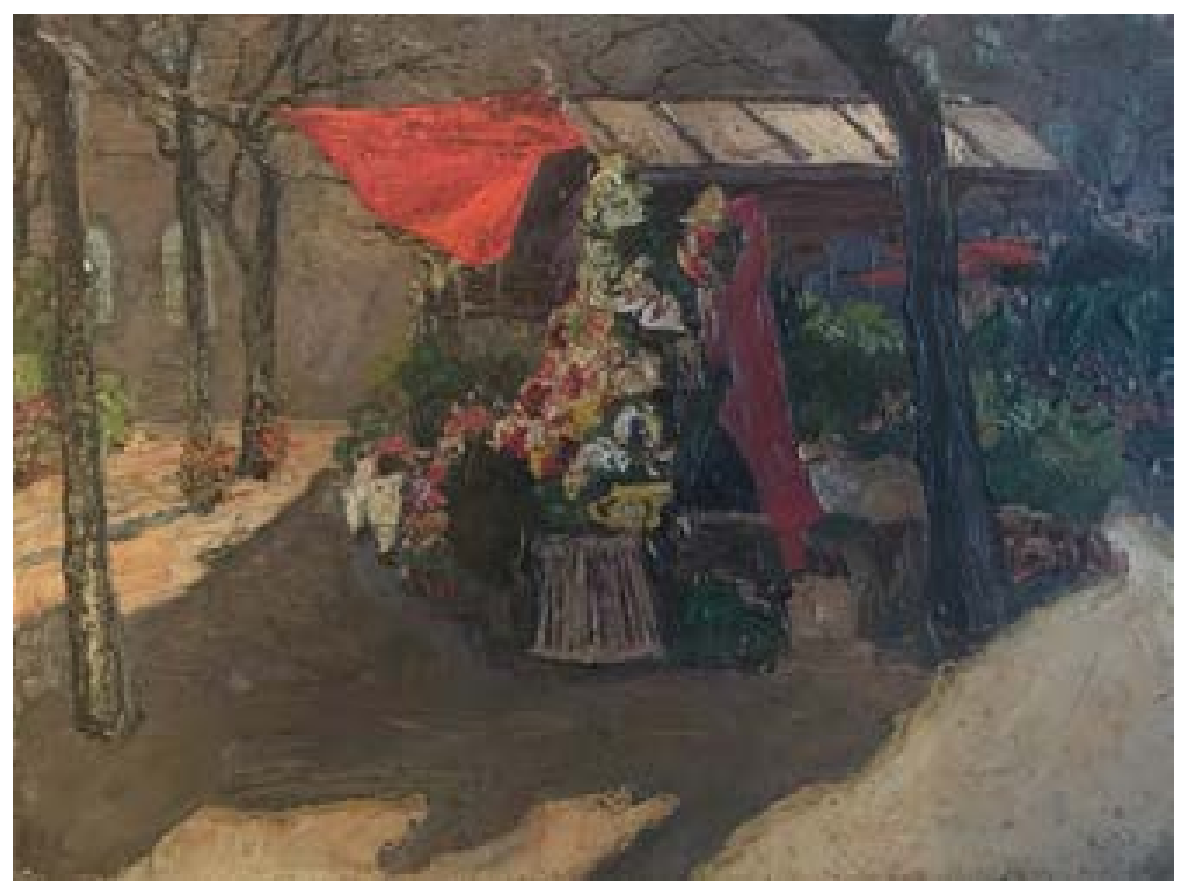

Uvodskaja E. Marche aux Fleurs. 1909. Paris.

School of the Academy. After her marriage (1905), before giving birth to her first child, she took a long vacation, went abroad with her husband and in December 1906 "dropped out without completing the course". Having returned from abroad, Elizaveta Vladimirovna moved with her son to live with her parents. In the personal file of the artist, correspondence with the school office was preserved. Thus, in the summer of 1910, she asked to send her the documents necessary for teaching at school, first to Belsk, then to Mendelinsk of the Ufa province. Despite the everyday difficulties associated with the birth of the second and third sons, the artist continued to work and exhibit with her husband.

While studying in St. Petersburg, the Protopopovs took a number of long trips along the Volga, Kama, and the outskirts of Ufa, as evidenced by the certificates issued by the academic office in such cases in which the Imperial Academy of Arts requested government and public institutions to assist the student and his wife in their work. A certificate was issued for a period of one year. According to the similar evidence available in the Protopopov case, we learn that the couple made trips for sketching from April to September in 1907, 1908, 1909 and 1911. During their travels, they not only made sketches, but also carried out custom jobs by painting small churches in the towns in the Volga region. In 1907-1909, the Protopopovs participated in the exhibitions of the Kuindzhi Society and the Lemercier Gallery [5. P.99]. During her studies and until 1917, E. Uvodskaya was 


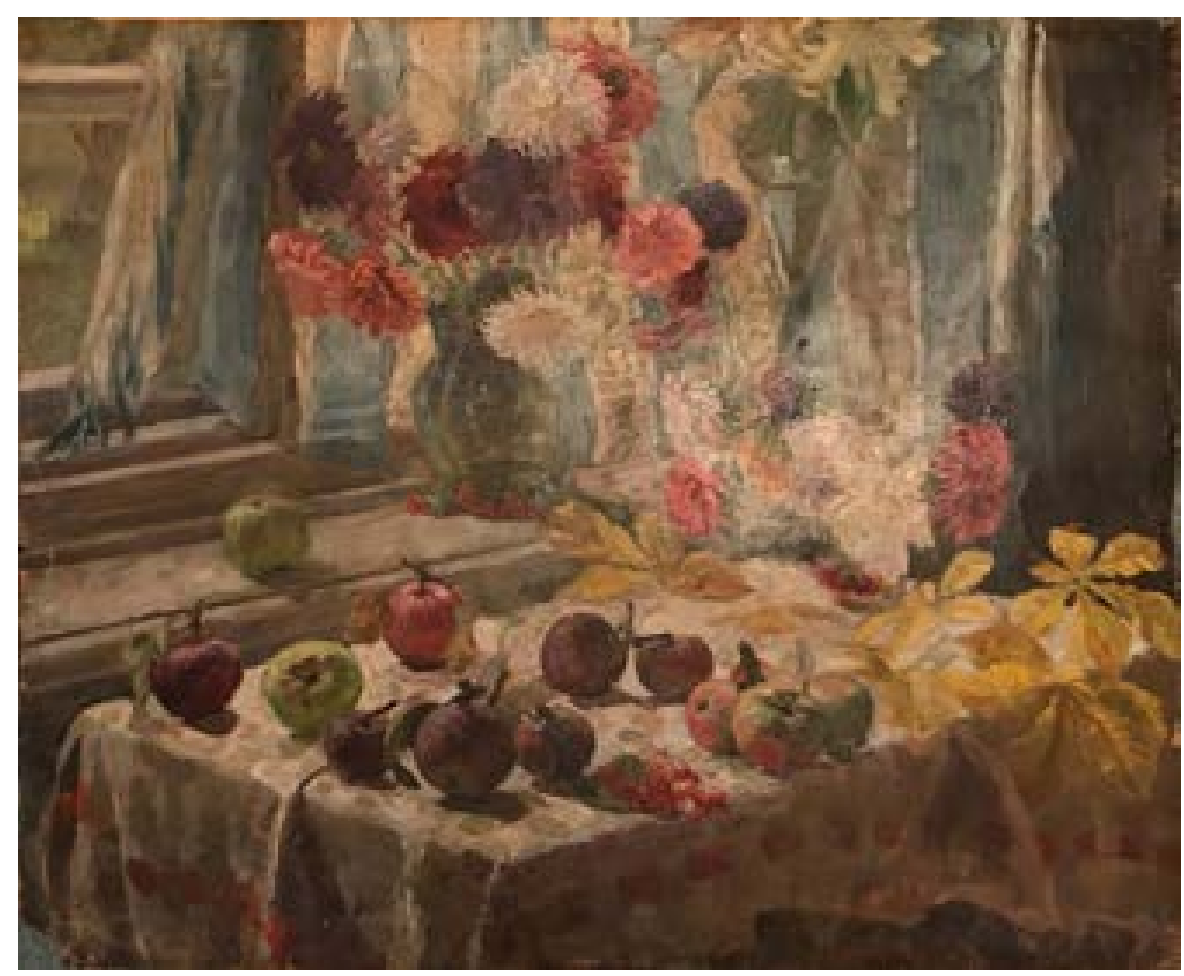

Uvodskaya E. Apples on the Table. Oil on canvas, late 1930s

among the regular exhibitors of the Association of Artists of St. Petersburg (19041924), in the Spring Exhibitions held in the halls of the Academy of Arts (19101916). She exhibited under the maiden name Uvodskaya, and as UvodskayaProtopopova in the 1930s. Her favourite genre was still life. In this genre, she created miniature works, easel paintings and decorative panels. In the 1930s, her name is found in the catalogs of exhibitions of the regional branch of the Union of Artists (LO SSH) and the City Committee of Art. In March 1937, Uvodskaya's works were exhibited at the Exhibition of paintings by Leningrad women artists. In the booklet "Painting. Sculpture. Graphics. Lenizo. Leningrad, 1937", the names of 14 participants were present. A. Ostroumova-Lebedeva, M. Aslamazyan, V. Semenova-Tyanshanskaya, E. Uvodskaya were among them. I published all this information in the article mentioned above on the Protopopov family. However, I managed to see the works of the artist only after many years, after the death of the stepdaughter of her son Anatoly. A small sketch depicting a flower stall in Paris, several still lifes and sketches to them are just a little that has been preserved.

As a rule, the works that were neither intended for display nor for sale, but which were very dear to the author, remained forever in the family or in the artist's workshop. This is precisely the very happy event that gives the researcher 
the opportunity to delve deeper into the artist's plan, to catch his feelings. The discovered works of the artist make it possible to make such broad generalizations due to the fact that they do not fit into the typological framework, which is drawn and set by schemes of structural approaches.

The study Paris. Marche aux Fleur (Flower Market) kept the memory of the years of study, of Parisian impressions, of the birth of the first son of Anatoly (1906). An awkward, hastily built flower stall, consisting of dissimilar fragments: painted metal sheets of the roof fastened with crossbars, red fabric of the curtain and bright swirling foam of flower bouquets are painted in a temperamental, expressive way. The simple and clear existential meanings of the disorder of life and hope inspiring the overcoming of dreams may be seen in the choice of such an inconspicuous motive and its energetic interpretation.

All the known today artist's still lifes were created during the 1930s. The still life with the inscription on the back of Assortment in a Vase is the earliest of them judging by the picturesque style stylistically close to the subject compositions of the late avant-garde, by its easel painting style. In this work, the author's special approach to the implementation of the modernist model of artistic integrity is expressed in the original interpretation of the dialogue between the avant-garde and the classics. The artist creates her synthesis model not by the method of cubist reconstruction of the classical form, but by the method of classical interpretation of the cubist programme. In the complex semantics, in the multiplicity of connotations of the work, impulses of a wide range of sources of inspiration are captured. Allusions to Jack of Diamonds painting, medieval craft tradition, an appeal to the philosophical meanings of the Spanish still life of the 17th century are seen. As close as possible to the viewer large scale subject composition, an all-pervading silver tone, softening the gloomy tense colour, contrasts of the texture and interpretation of forms, air vibrations created by the «worn» canvas gives some dramatism to the image. Here, still life as a genre demonstrates the new structures of the expressive language of painting, encrypting the content of the created work and generating a new imagery.

Later Uvodskaya's still lifes cannot be assigned to any of the periods established by the researchers for the transformation of this genre (for example, considering the beginning and the second half of the 1930s as separate stages), which is explained not so much by the absence of their dating as by the mismatch of the genre interpretation with general trends. In the same way, the artist's still lifes cannot be ranked among any of the custom-oriented types of this genre: romantic, official, salon, or to the lower level of the art market, where "sugared" signs of these types are present in the works addressed to the general public, displayed at the exhibitions of the All-Russian Cooperative Association «Artist» in work clubs and sold in its shops. The works under consideration belong to a special commonality in which the works are united according to the principle 
of secret and random birth as a result of deep reflection of their creator. In them, stable structures are destroyed, schemes are broken, meanings are interpreted differently, the innermost is symbolized. In particular, it can be noticed that the artist goes away from the principles of compositional structure which have become established in the genre, as if deliberately destroying the iconographic scheme of a still life. Her painting style was gradually changing, in which neoimpressionistic techniques evolved in the direction of a finer development of the pasty texture of the temperamental brushstroke, multi-valued symbolism of colour solutions. Such is the still life in which the artist depicted two vases with bouquets of wildflowers very close to each other. One is sumptuous, with large double heads of multi-coloured cloves, thick wet leaves covered in earth, and the other is immersed in the darkness, animated only by bright flashes of small flowers of complex plants.

Such a deviation from the classical iconography of the genre, in this case, is explained by non-specific associative perception, usually defined by the author as a state of mind, and by the search for means of expression, that is, a change in aesthetic preferences generating interest in a picturesque interpretation of impartiality, imbalance, randomness.

In terms of iconological-existential, the fine art of this time has been little studied, while here artists also used hidden symbolism. In such cases, it could have been not only about complex philosophical cryptograms, but rather about the atmosphere of social and political life, the artistic evaluation of which diverged from the propaganda [15.Pp.127-141].

Sokolov commented on the situation in which the artist, deprived of spiritual sovereignty, was looking for a way out: "In the 1930s, Soviet art not in real life, of course, but in state cultural policy, became a kind of working model for the formation of an extremely unified, extremely optimistic social consciousness. Therefore, the hunt for crypto symbol, which was really popular, was in the nature of the necessary public self-cleaning in the official outlook. However, contrary to this hunt, and partly because of it, the antagonistic gap between the upper, public, and the lower, independently individual, independently "circle" (or, in the current language, "secret") layers of aesthetic thinking continued to deepen which gave the Soviet art life of those years a special complexity, tragic tension and, at the same time, theatrical quaintness"10 [1. P.212]. Painted in Martyshkino in autumn, Uvodskaya's subject composition has no name, and the author's intention to interpret the emerged in the transformation of the genre tendency towards expansion, surrounded with accompanying motifs, in her own way may be seen in it. Her still life literally falls apart in front of the viewer. Instead of the tables neatly placed to the windowsills, which is typical for constructing such still

10. loc. cit. P.212 
lifes, with well-arranged grouped elements of the subject ensemble, here, the viewer's gaze from above rests on the corner. Turned toward it, there is a table with a carelessly put tablecloth with wrinkled folds and apples scattered all over it. Moreover, bouquets of autumn garden flowers in glass vases and other objects traditionally present in such compositions are decisively set aside and crowded along the edges of the table and near the windowsill. Apple Spas, representing a turn in nature, is associated with a turn in the mindset of the author, freed from illusions and experiencing relief. Perhaps in the future, new research would succeed and reveal miraculously surviving written evidence which would tell us important details of the artist's life and experiences, would help to clarify the connection between the image and the era [14.Pp.257-267]; they would help to understand what the two opposing motives meant: an apple - the polysemantic, eternal symbol, and the symbolic meaning of the accompanying pictorial motive - a part of a small window with a faded, washed-out piece of fabric of the curtain; what stood behind the expression of two moods, a joyful and enlightened sense of insight, unexpectedly gained freedom and at the same time narrowed to the limit clearly realized the reality of the picture of the world outside.

The work with which we finish the presentation of Elizabeth Uvodskaya's still lifes is inspired by the artist's reaction to the attributes of representativeness of the official and salon types of this genre: an abundance of antique tableware, smallscale sculpture, furniture, motifs of classical drapery, etc. All of these are present in the artist's subject composition but in a completely different role. Items made of fabric and decorated with golden embroidery are the basis of the still life. In the golden twinkling of the decor, the eye barely distinguishes individual objects of expensive dinner sets, miniature porcelain figures immersed in the folds of fabric. Carelessly laid out and arranged, lost in the diversity of poorly assembled pieces of sewing, the tableware and statuettes are not perceived at all as those beautiful objects which make up a perfectly constructed still life. These objects are endowed with purely symbolic functions and are located in the symbolic space of an artistic metaphor hiding the idea of the loss of spiritual values. The symbol is distributed and the atmosphere created by the language of painting takes on a symbolic meaning [11.P.146]. The colour scheme created with tone gradations and subtle colour changes give the image an emotional colouring.

By understanding the content of the works of both artists, we find out that the connection of their work with the era happened in the form of a response to a challenge. The iconological method of reading cultural meanings, unraveling symbols helps to identify their style, semantics and symbolism, the assertion of another reality, the creators of which are creative individuals, in the structure of these works. Such a deep understanding of the world of art allows to identify different layers of spiritual reality and get a clearer picture of the cultural life during the era. 


\section{REFERENCES:}

Articles from Scientific Journals

1. Barnaby, Haran. 2015. Tractor Factory Facts: Margaret Bourke-White's Eyes on Russia and the Romance of Industry in the Five-Year Plan. Oxford Art Journal, Volume 38, Issue 1, pp. 73-93. DOI 10.1093/oxartj/kcu032

2. Azatyan, Vardan. 2010. "Ernst Gombrich's Politics of Art History: Exile, Cold War and The Story of Art", Oxford Art Journal, Volume 33, Issue 2, pp. 127-141. DOI 10.1093/oxartj/kcq012

3. Damisch, Hubert. 2005. "Eight Theses For (or Against?) A Semiology of Painting." Oxford Art Journal, Volume 28, Issue 2, pp. 257-267

4. Wilson, S 1980, “"La Beauté Révolutionnaire?” Réalisme Socialiste and French Painting, 1935-1954", Oxford Art Journal, vol. 3, no. 2, pp. 61-69.

5. Gray, Camilla (Gray, Camilla). 1960. "The Russian Contribution to Modern Painting”, Burlington Magazine, 05/1960, pp.686, 102. pp. 204-211.

Articles from Proceedings and Collections of Research Papers

6. Barkovskaya, O. 2015. "Odessa Art School. Chronicle of 1865-1940.", News of the Odessa Art Museum. 2. P.133, Odessa.

7. Burliuk, D. 1988. "Memoirs of the Father of Russian Futurism.", The Past. Historical almanac. 5, p.27, Paris.

8. Malinina, T. 2006. "Artist N.Protopopov and his Family. Experience in Biographical Research.”, The Study of a Scientist. Scientific articles, publications, essays, pp.94-110, Moscow.

9. Sokolov M. 1991."Iconology and Questions on the Study of Soviet Art. On the Problem of Hidden Symbolism», Style. Image. Time. Moscow: Research Institute of the Russian Academy of Arts

\section{Monographs}

10.Alpatov, M. 1939. Italian Art of Dante and Giotto Era. Moscow, p. 153.

11. Boehm, G. 2014. O Obrazach i Widzeniu. Antologia Tekstow, Ed. D. Kolacka, tlum.Lukasiewicz, A.Pieczynska Sulik. Krakow, p. 146.

12. Panofsky, E. 1960. Renaissance and Renascences in Western Art: in 2 Volumes. Stockholm: Almquist and Wiksell, pp.141-142.

13. Panofsky, Erwin. IDEA. On the history of the Concept in Terms of Art from Antiquity to Classicism. AXIOMA. St. Petersburg. 1999. Pp.78,85,86.

14. Wilhelmi, Chr, 1980. Handbuch der Symbole in der bildenden Kunst des 20 Jhs. Frankfurt - am - Main - Berlin

Source

15. Exhibition of Artist N. Protopopov's Works. Catalog. Lenizo, 1951.

16. The Case of the Student E.Belyaeva (Uvodskaya). Q.v.: RGIA SPb. VHUIAH. Fund.789. F. 12.1903 D.I. P.96. 
Thesis and Thesis Abstracts после Monographs

17. Khuzina, Tatyana E.. 2009. Predmetnyy mir v sovetskoy zhivopisi 1930$x$ gg.: semanticheskiy analiz [The subject world in Soviet painting of the 1930s: semantic analysis ] PhD Thesis Abstracts. Saint - Petersburg (in Russian) 


\section{Татьяна Глебовна Малинина}

доктор искусствоведения, профессор

главный научный сотрудник

Научно-исследовательского института

Российской академии художеств

e-mail:tgmal01@yandex.ru

Россия, Москва

ORCID 0000-0003-0785-305X

DOI: 10.36340/2071-6818-2019-15-3-139-168

\section{О методах изучения художественных процессов эпохи модернизма. Комментарии к ст. М.Н.Соколова «Иконология \\ и вопросы изучения советского искусства - к проблеме “скрытого символизма"» 1}

Аннотациия: предлагаемая статья развивает тезисно изложенные положения доклада на конференции НИИ теории и истории изобразительных искусств РАХ «Образ и сюжет в визуальных искусствах. Поэтика: от древности до современности» (Х.2018), посвященной памяти Михаила Николаевича Соколова, последовательного и талантливого продолжателя интерпритационных стратегий иконологического метода Э. Панофски . Автор обращается к мало известной статье замечательного ученого, опубликованной в одном из репринтных сборников НИИ РАХ (1991). Размышления Соколова о проблемах методологии, применении иконологического анализа, связанные с изучением искусства нового и новейшего времени, в частности, искусства соцмодернизма, актуализируют содержание его статьи. Чтобы ответить на вопрос, каким был духовный мир человека XX столетия, как отразились в нем трагические события века, нужны особые инструменты. Те инструменты, которыми сравнительно недавно пользовался исследователь для изучения отношений художника с обществом, социальным заказом, с политической системой, диктатом власти, не могут способствовать решению новых, возникаюших сегодня вопросов. Поэтому первостепенное значение начинают приобретать поиски метода «извлечения» искомого знания о духовной жизни художника эпохи модернизма. Публикуемая статья является осмыслением и своеобразным комментарием к методологическим стратегиям, предложенным М.Н.Соколовым. Соотнесение с ними собственного опыта многолетней работы по изучению художественного творчества эпохи мо-

1. Соколов М.Н. «Иконология и вопросы изучения советского искусства - к проблеме

“скрытого символизма"».- С.198-216// Стиль - Образ - Время. М.: НИИ РАХ, 1991 
дернизма служит дополнительным аргументом в пользу применимости и эффективности иконологического метода.

Статья имеет трехчастное строение. В первой части рассматриваются положения указанной статьи М.Н.Соколова. Вторая и третья части статьи посвящены иконологическому анализу произведений двух живописцев / Санкт-Петербург-Ленинград/ : пейзажей Н.А.Протопопова ((1876 -1960) и натюрмортов его жены Е.В.Уводской(1875-1943). Иконологический анализ произведений Н.А.Протопопова показывает наличие семантических подтекстов, символического содержания, свидетельствующих о явном несовпадении ценностных ориентиров художника и ходульной риторики официозного нарратива в отношении к происходящим событиям. Творчество жены художник Елизаветы Владимировны Уводской в силу особых жизненных обстоятельств предстает совершенно не изученным: работы -затерявшимися в потоке событий первой мировой войны и революции, поглощенными стихийным рынком периода НЭПа и утраченными уже в послевоенные годы, а документы, письма, дневники - израсходованными на растопку печи в блокадном Ленинграде. Елизавета Владимировна умерла во время блокады в 1943 году. Анализируемые натюрморты художницы публикуются впервые. Иконологический метод считывания культурных смыслов, разгадывания символов, помогает выявить в структуре произведений обоих художников, их стилистике, семантике и символике утверждение другой реальности.

Ключевые слова: методологический арсенал современного искусствознания, методы анализа искусства ХХ-ХХІвв., М.Н.Соколов о применении метода иконологии в исследованиях искусства советского периода, принциип «скрытого символизма» в теории Э.Панофски, примеры иконологического анализа.

$$
\begin{array}{r}
\text { «.. каждая личность носит в самой себе свои } \\
\text { иели и, } \\
\text { между тем, носит их для того, } \\
\text { чтобы служить недоступным человеку ицелям } \\
\text { общим» } \\
\text { Л.Н.Толстой «Война и мир». Эпилог }
\end{array}
$$

Стремясь пополнить методологический арсенал современного искусствознания, теоретики обосновывают синтетический принцип, объединяющий аналитические приемы формально-стилистического, культурологического, структуралистского, деконструктивистского и других методов. Современная наука приходит к выводу о возможности распространения на искусство XX - начала XXI века методов анализа, применявшихся их основоположниками лишь в рамках исследуемых ими периодов античности 
и средневековья либо Ренессанса и барокко. М. Н. Соколов, в частности, отмечает в одной из своих статей ${ }^{2}$, что, если сам Э. Панофски достаточно скептически относился к возможности иконологического взгляда на искусство XIX - XX веков, когда, казалось бы, иконографические каноны сошли на нет, сменяясь более или менее свободным художественным выбором тем и образов, то современные исследователи приходят к противоположному заключению, утверждая, что устойчивая сюжетно-тематическая типология, равно как и строго определенные символические структуры, оказываются столь же характерными и для древнего, и для современного, в том числе новейшего, эстетического мышления [1. С.199-200]

В качестве ценного дополнительного аргумента в пользу применимости иконологического метода для изучения современного искусства М.Н. выдвигает принцип «скрытого символизма». Этот принцип, поясняет он, первоначально выявленный Э. Панофски и К.Тольнаем на материале живописи нидерландского позднего средневековья, предполагает органическое сосуществование средневекового символизма и ренессансного мимесиса в пределах одного образа. Средневековая эстетика конструировала мир символов, открыто нарушающий эмпирические навыки зрительного восприятия. Иносказательное значение само по себе не маскировалось, а выступало наглядно, существуя как бы параллельно художественной форме, подобно тому, как в теологических упражнениях по изучению Священного Писания вслед за изложением текста неизменно следовал вопрос: «Как сие понимать духовно?». Принцип скрытого символизма, утверждает Панофски, начинает действовать с того момента, как картинное пространство подчиняется законам пространства эмпирического, и художнику приходится скрывать теологические и символические смыслы, которые его предшественники демонстрировали открыто, под облачением внешнего правдоподобия. ${ }^{3}$ [2. С.141-142]. По аналогии с целостностью, достигаемой прочным союзом раннереалистического метода и метафорической условности, М.В. Алпатов, описывая сходные феномены, уже вводит термин «реалистические символы»[4.С. 153 ]. Комментируя эту мыслительную процедуру, М.Н. Соколов подчеркивает ошибочность застарелого предрассудка противопоставления «символического» средневековья и «реалистического» нового времени, по сути своей якобы враждебного условно-метафорическому взгляду на мир. Сложившийся стереотип, толкующий символизм средневековья как антитезу «реализму » Ренессанса, оказался весьма распространенным и в науке об искусстве нашего века. Теперь же «символический» модернизм искусственно противопоставляется реализму, более традиционным формам художественного видения, где метафоры, если и играют, то якобы сугубо

2 Указ. соч. С. 199

Panofsky E. Renaissance and Renasences in Western Art. Stockholm. 1960. P.141-142 
второстепенную роль. « Обилие иносказаний характерно для всех этапов развития модернистской эстетики от «модерна» до сюрреализма и далее, замечает он. - Часто последовательные стадии явления или маскировки символа самым непосредственным образом включаются в художественную ткань, как, например, в ранних беспредметных композициях В. Кандинского, где изобразительные знаки (ладья, церковные купола, гора, всадники и т.д.) как бы выплывают на время из стихии абстрактных форм, затем вновь в них скрываясь» ${ }^{4}$ [1. С.204]

Проделанный исследователем в упомянутой статье иконологический анализ нацелен на конкретику образного восприятия искусства 1920-х 1930-х годов его современниками [ 12.Р.204-211; 13. Р.61-69] . Оценивая этот опыт, автор отмечает, что в результате анализа выявляется богатая ассоциативная ткань произведений, Различные криптоиконографические художественные ходы во многих случаях помогают уяснить связь образа и эпохи с особой наглядностью и даже позволяют прогнозировать не только эстетические симпатии, но и реакцию на изменения социально-политического климата своего времени. Автор утверждает также, что иконологический анализ применим к любому художественному явлению модернизма, в том числе и к искусству соцмодернизма, имея в виду не только освещенный в статье материал двух десятилетий, но и первые послевоенные годы, «оттепель», период застоя, изучая которые можно найти массу разнообразных примеров криптоиконографии.

В заключение автор советует заинтересованному читателю при углубленном изучении данного феномена помнить максиму Паскаля, т.е. не делать двух ошибок: 1. Воспринимать все буквально и 2. Воспринимать все духовно (т.е. иносказательно). «Избегая этих крайностей, - резюмирует он, - совмещая понимание внешних историко-стилистических обстоятельств с проникновением в символическую перспективу, искусствоведение может открыть немало новых неожиданных граней как отечественной, так и зарубежной культуры нового и новейшего времени» ${ }^{5}$ [1. С.214 ]

В перспективу поля исследований Соколов включает не только независимые социальные наблюдения художника, но и обращение к религиозным сюжетам и символам. И, действительно, все, кто исследует сегодня искусство эпохи модернизма, встречаются с необходимостью разгадывания визуальных шифров, связанных с религиозной символикой.

Приведу примеры из собственного опыта, в частности, работы над исследованием творчества малоизвестного санкт-петербургского живописца

\footnotetext{
4. Указ. соч..- С.204

5. Указ. соч.- С.214
} 
Николая Адриановича Протопопова ${ }^{6}$ [5. С.94-110] и его жены Елизаветы Владимировны Уводской.

Они были сверстниками, оба посвятили жизнь одной профессии, оба получили духовное и светское образование, оба встретили революцию состоявшимися личностями. Каждый из них, тем не менее, шел своим творческим путем, и голоса их различимы в историческом времени.

Детство и юность Н.А.Протопопов провел в Бирске, где отец его служил протодиаконом. В Бирске он закончил приходское училище, в Уфе - духовное училище и семинарию. Затем поступил в Казанскую духовную академию и со второго курса стал одновременно посещать занятия в Казанской художественной школе. После завершения обучения в духовной академии он учился три года в художественной школе, которую закончил с правом поступления в Высшее художественное училище Императорской академии художеств в 1903 году. Звание художника ему было присвоено в 1912 году за картину «После бурной ночи» (холст, масло, 2,5х3 ; мастерская Н.Н.Дубовского). Работа утрачена. Мы знаем о ней только по заметкам журнала «Мир искусства» и детским воспоминаниям внуков художника. Однако даже из словесного описания создается впечатление, что автор обогащает традицию апокрифической живописи Н.Н.Ге колористической и иносказательной образной эзотерикой символизма. Дипломная работа была удостоена премии Ивана Ивановича Ендогурова, которая присуждалась за лучший пейзаж. Представление о стилистике и образных возможностях современного пейзажа сформировалось у художника во время поездок в Париж и Лондон, Венецию и Мюнхен. Его привлекает язык позднеимпрессионистической живописи, глубоко волнует искусство прерафаэлитов, он проявляет интерес к позднему Возрождению и маньеризму, а также немецкому искусству рубежа веков. Постижение разных языков живописи, разных взглядов на мир, преломленное в сознании художника, помогает ему приблизить высокое и одухотворить близкое. Этот синтез сулил рождение качественно новой образности и стилистики, богатых возможностей их осмысления в разных трактовках пейзажного жанра. В русской интерпретации новой образности, по убеждению художника, следовало основываться на идеях Нестерова и Левитана, избегая при этом литературности. Поиски путей воплощения идеи пейзажа-картины, переход от этюда к большому полотну отмечается в творчестве художника, начиная с 1910-х годов. В дальнейшем вплоть до середины 1920-х в творчестве живописца будет ощущаться напряжение внутреннего диалога вечного с сиюминутным. Об образных превращениях на пути от этюда к картине у Протопопова можно судить по многочисленным

6. Малинина Т.Г. Художник Н.А. Протопопов и его семья. Опыт биографического исследования. С.94-110// Кабинет ученого. Научные статьи, публикации, эссе. М.: Прогресс-Традиция.. 2006 
его работам на тему «Природа-храм». Не случайно художник, как правило, показывал на выставке этюд и картину на одну тему (например, наиболее известную работу «Мирожский монастырь»). Большое полотно 1917 года, названное «Половодье», с его бескрайним серым небом пасмурного дня, уродливыми глыбами плывущего по реке льда, навеянное смутными предчувствиями больших перемен, обозначает решительный поворот в творчестве художника к скрытой символизации образов. То, что вырабатывалось опытом непосредственного общения с натурой, то, что воспринималось от модернистской эстетики, по-своему преломлялось и в конце концов готово было вылиться в мощные синтетические образы, оказалось растворенным и строго дозированным в произведениях 1930-х годов. Причины ясны, и мы оставим их за рамками повествования. Важно увидеть, как теперь воплощается идеал художника, в чем он находит смысл и утешение, есть ли в его произведениях нечто, побуждаемое желанием выразить несогласие, возразить, противостоять внешним обстоятельствам. Этого у художника нет, но есть чистый, незамутненный взгляд на мир, присущий также настроению и кроткой интонации произведений писателей М. Пришвина и И. Шмелева, художников В.Фаворского и бр. Чернышовых, в которых мир Божий велик, разнообразен, и красота его явлена всюду.

Расширение тематического диапазона пейзажа, характерное для станковой живописи 1930-х годов, проявляется и в творчестве Николая Адриановича Протопопова. Однако на совпадении с общей тенденцией к углублению содержания произведения заканчивается соответствие официальному заказу[16. Р.73-93], поскольку происходит расхождение в понимании значения этой глубинности. Кажется, легко, без особых усилий в иносказательнопоэтической трактовке сюжета художником происходит подмена аллюзий. Работы живописца лишены пафосной риторики, взгляд его внимателен и сосредоточен, а пейзажи, включающие архитектурные мотивы, элементы жанровой или сюжетно-тематической живописи, носят характер библейского повествования. Природа предстает в них удивительным образом сочетающей достоинство и молчаливое сочувствие. То, что совершается в ней, выглядит неторопливым ритуальным действием. Ловля рыбы («Рыба озера Имандра», «Богатый улов», «Разгрузка судов на Северной реке») или весенняя пахота («Весна») изображаются как вечный, Богом установленный для человека порядок. В понимании основ бытия, воплощаемом в произведениях живописца, важной частью аутентичности образов мыслимого и зримого является идея сокрытого Бога. Она улавливается зрителем благодаря подвижности и прозрачности самой структуры образа, его многоликости и недосказанности как символов времени в творчестве мастера. Именно эти качества сделали Н.А. Протопопова «художником второго ряда» в глазах критики тех лет, требовавшей большей конкретности и определенности 
в выражении связи с эпохой. Таким образом кажущаяся неосуществимой в данных исторических условиях мечта живописца о пейзаже-картине глубокого философского содержания все-же осуществляется в названных тематических полотнах предвоенного периода, а также в произведениях военных лет, свидетельствуя о возможности сохранения духовного суверенитета от идеологического диктата.

В 1942 году Н.А. Протопопов создает хранящуюся сегодня в Русском музее картину «Пожар» ${ }^{7}[$ 6. Каталог]. Хотя художниками и архитекторами осажденного города было сделано множество натурных зарисовок во время страшных блокадных пожаров, когда горели склады с продовольствием, горючими материалами и боеприпасами, верфи, депо, заводы, послуживших основой большого числа станковых работ, в большинстве своем они оставались жанровыми произведениями. Протопопов же создал эпическое полотно, показав, что овладел тайной превращения живописной материи из зримого образа в образ-символ. Огромное облако, нависшее над городом, становится предвестником большой беды и тяжелых испытаний. При этом панорама, открывающаяся со стрелки Васильевского острова, так прекрасна, голубизна неба так ослепительна, что кажется, будто город существует в другом измерении, в мире горнем, оставаясь недоступным, недосягаемым для сил разрушения. Надвигающаяся катастрофа встречена с достоинством, кротостью и надеждой. Иконологический анализ показывает наличие семантических подтекстов, символического содержания, свидетельствующих о явном несовпадении ценностных ориентиров художника и ходульной риторики официозного нарратива в отношении к происходящим событиям. Иными словами, символизация образов искусства военных лет инспирирована импульсами независимого мышления личного свойства. Сила человеческого духа вызывала к жизни в этот момент глубинные бытийные смыслы, по сути - вневременные [7].

Творчество жены художник Елизаветы Владимировны Уводской в силу особых жизненных обстоятельств предстает совершенно не изученным: работы -затерявшимися в потоке событий первой мировой войны и революции, поглощенными стихийным рынком периода НЭПа и утраченными уже в послевоенные годы, а документы, письма, дневники - израсходованными на растопку печи в блокадном Ленинграде. Елизавета Владимировна умерла во время блокады в 1943 году.

Когда в начале 2000-х годов я собирала материалы для статьи о Н.А.Протопопове, в архивах РАХ и РГИА СПб обнаружились и важные сведения биографии художницы, в частности, время и место ее рождения. Е.В.Беляева (урожденная Уводская) родилась 2 апреля 1875 года в селе

Выставка произведений художника Н.А.Протопопова. Каталог. Ленизо. 1951 
Богородском Уфимского уезда в семье священника. В книге М.В.Нестерова «Давние дни» мы находим упоминание об этом селе. Художник повествует о том, что любимым местом для прогулок молодежи Уфы была Шихан-гора на берегу реки Белой. «Отсюда и село Богородское видно: в двух шагах мужской монастырь. Какие дали оттуда видны! Там начало предгорий Урала, и такая сладкая тоска овладевает, когда глядишь в эти манящие дали!»

В деле учащейся ВХУ ИАХ содержатся следующие сведения. 3 сентября 1890 года дочь протоирея Владимира Васильевича Уводского и его супруги Пульхерии Аркадьевны, девица Елизавета Уводская 17 лет была принята в число воспитанниц Уфимского епархиального женского училища, полный курс которого окончила в 1893 году с правом на звание домашней учительницы [8. Ф.789. Оп.12.1903 ].

В течение последующих десяти лет Елизавета Уводская обучалась в Казанской художественной школе и в Одесском художественном училище. О том, что будущая художница занималась в Одесском художественном училище, стало недавно известно из опубликованных в 1988 году воспоминаний Д.Бурлюка: «1900/01 ... Из учившихся со мной я помню по фамилиям Петра Максимовича Дульского, Ивановскую, Гермогена Цитовича - внука Аксакова, очень одаренного человека, которому война и необыкновенная щепетильность помешали стать хорошим сезанистом. Еще помню также Уводскую, Давыдова и Добрынина» ${ }^{8}$ [9. С.27 ] Училище, созданное на базе Рисовальной школа Одесского общества изящных искусств в 1900 году, пользовалось популярностью среди художников и приобрело солидную репутацию как учебное заведение. Его выпускники получали право на звание преподавателей рисования и черчения в средних учебных заведениях и льготный прием в Императорскую академию художеств 9 . [ 10. С.133]. После его окончания в 1903 году Елизавета Уводская была принята в Высшее художественное училище Академии. После замужества (1905) перед рождением первого ребенка она оформила длительный отпуск, уехала с мужем за границу и в декабре 1906 года «выбыла, не окончив курса». Вернувшись из-за границы, Елизавета Владимировна уехала с сыном к родителям. В личном деле художницы сохранилась переписка с канцелярией училища. Так летом 1910 года она обращается с просьбой выслать необходимые для преподавания в школе документы сначала в Бельск, затем в Менделинск Уфимской губернии. Несмотря на житейские трудности, связанные с рождением второго и третьего сыновей, художница продолжала работать и выставляться вместе с мужем.

8. Бурлюк Д. Воспоминания отца русского футуризма. С.27// Минувшее. Исторический альманах. 5. Copyright by Atheneum.1988. Paris

9. Барковская О.М. Одесское художественное училище. Хроника 1865-1940. С.133// «Вісник Одеського художнього музею».2. 
В период учебы в Петербурге Протопоповы предприняли ряд долгих путешествий по Волге, Каме, окрестностям Уфы, о чем говорят выдаваемые академической канцелярией в таких случаях свидетельства по специальной форме, в которых Императорская академия художеств обращалась с просьбой к правительственным и общественным учреждениям о содействии ученику и его жене в их работе. Свидетельство выдавалось сроком на год. По имеющимся в деле Протопопова подобным свидетельствам мы узнаем, что поездки на этюды с апреля по сентябрь супруги совершали в 1907, 1908, 1909 и 1911 годах. Во время своих путешествий они не только писали этюды, но и выполняли заказы на росписи небольших церквей в поволжских городах. В 1907 - 1909 супруги Протопоповы участвовали в выставках Общества им.А.И.Куинджи, Галереи Лемерсье [5. С.99]. Во время учебы и вплоть до 1917 года Е.В.Уводская была в числе постоянных экспонентов «Товарищества художников Санкт-Петербурга»(1904-1924), в «Весенних выставках», проходивших в залах Академии художеств (1910-1916). Выставлялась она под девичьей фамилией Уводская, а в 1930-е годы - Уводская-Протопопова. Её излюбленным жанром был натюрморт. В этом жанре она создавала миниатюрные работы, станковые картины и декоративные панно. В 1930-е годы ее имя встречается в каталогах выставок областного отделения Союза художников (ЛО ССХ) и Горкома изо. В марте 1937 года работы Уводской экспонировались на Выставке картин ленинградских женщин-художниц. буклете «Живопись. Скульптура. Графика. Ленизо. Л., 1937» названы имена 14 участниц. Среди них - А.П. Остроумова-Лебедева, М.А. Асламазян, В.Д. Семенова-Тяньшаньская, Е.В. Уводская. Все эти сведения я опубликовала в упоминавшейся выше статье, посвященной семье Протопоповых. Однако сами произведения художницы мне удалось увидеть только спустя много лет, после смерти падчерицы ее сына Анатолия. Небольшой этюд, изображавший цветочный киоск в Париже, несколько натюрмортов и этюдов к ним - вот то немногое, что сохранилось.

Как правило, в семье или в мастерской художника остаются навсегда те работы, которые не предназначались ни для показа, ни для продажи, но были чем-то очень дороги автору. Это как раз тот самый счастливый случай, который дает исследователю возможность глубже вникнуть в замысел художника, уловить чувства, которые им владели. Обнаруженные произведения художницы позволяют делать такие широкие обобщения, потому что не встраиваются в типологические рамки, которые вычерчены и заданы схемами структуральных подходов.

Этюд «Paris. Marche aux fleur»(«Цветочный рынок») хранил память о годах учебы, о парижских впечатлениях, о рождении первого сына Анатолия (1906). Неуклюжий, наскоро сбитый цветочный киоск, состоящий из разнородных фрагментов: крашеных металлических листов кровли, скреплен- 
ных поперечными рейками, красного лоскута занавески и яркой клубящейся пены цветочных букетов, написан темпераментно, экспрессивно. За выбором столь невзрачного мотива и его энергичной интерпретацией угадываются простые и ясные экзистенциальные смыслы неустроенности жизни и вселяющие надежду на её преодоление мечты.

Все известные сегодня натюрморты художницы относятся к 1930-м годам. Самым ранним из них, судя по живописной манере, стилистически близкой предметным композициям позднего авангарда, его станковистскому направлению, является натюрморт с надписью на обороте « Ассорти в вазе». Особый подход автора к реализации модернистской модели художественной целостности выражается в оригинальной интерпретации диалога авангарда и классики в этой работе. Свою модель синтеза художница создает не методом кубистической реконструкции классической формы, а методом классической интерпретации кубистической программы. В сложной семантической ткани, в множественности коннотаций произведения, улавливаются импульсы широкого круга источников вдохновения: прочитываются аллюзии бубнововалетовской живописи, средневековой ремесленной традиции, апелляция к философским смыслам испанского натюрморта XVII в. Крупный масштаб максимально приближенной к зрителю предметной композиции, всепроникающий серебристый тон, смягчающий мрачноватый напряженный колорит, контрасты фактуры и трактовки форм, воздушные вибрации, создаваемые «затертостью» холста придают драматическое звучание образу. Натюрморт как жанр демонстрирует здесь новые структуры выразительного языка живописи , шифрующего содержание создаваемого произведения и порождающего новую образность.

Более поздние натюрморты Уводской невозможно отнесения ни к одному из установленных исследователями периодов трансформации этого жанра (например, рассмотрение начала и второй половины 1930-х годов как отдельных этапов ), что объясняется не столько отсутствием их датировки, сколько несовпадением жанровой трактовки с общими тенденциями. Точно так же натюрморты художницы нельзя причислить ни к одному из ориентированных на заказ типов этого жанра: романтическому, официальному, салонному или к низовому уровню художественного рынка, где «рассиропленные» признаки названных типов присутствуют в адресуемых широкому зрителю произведениях, демонстрируемых на выставках «Всекохудожника» в рабочих клубах и продаваемых в его лавках. Рассматриваемые работы принадлежат к особой общности, в которой произведения объединяются по принципу тайного и случайного рождения в результате глубокой рефлексии их создателя. В них разрушаются устойчивые структуры, ломаются схемы, по-иному истолковываются смыслы, символизируется сокровенное. Можно заметить, в частности, что художница отступает от утвердившихся 
в жанре принципов композиционного построения, как бы сознательно разрушая иконографическую схему натюрморта. Постепенно менялась и ее живописная манера, в которой неоимпрессионистические приемы эволюционировали в направлении более тонкой разработки пастозной фактуры темпераментного мазка, многозначной символики цветовых решений. Таков натюрморт, на котором художница изобразила две вазы с тесно прижатыми друг к другу букетами полевых цветов - пышного, с крупными махровыми головками разноцветной гвоздики, густыми мокрыми, вывоженными в земле листьями, и погруженного в темноту плотного, оживляемого яркими вспышками мелких цветков сложноцветных растений.

Такое отступление от классической иконографии жанра, в данном случае объясняется неконкретно-ассоциативным восприятием, обычно определяемым самим автором как «состояние души», и поиском средств его выражения, то есть сменой эстетических предпочтений, порождающих интерес к живописной интерпретации непредвзятости, несбалансированности, случайности.

Изобразительное искусство этого времени в плане «иконологически экзистенциальном» мало изучено, в то время как и здесь художники также прибегали к скрытой символике. В подобных случаях речь могла идти вовсе не о сложных философских криптограммах, а скорее об атмосфере общественно - политической жизни, собственная художественная оценка которой расходилась с пропагандистскими установками [15.P.127-141].

М.Н. Соколов так комментирует ситуацию, в которой художник, лишенный духовного суверенитета, искал выход: « В 1930-е годы советское искусство, конечно, не в реальном его бытовании, а в государственной культурной политике, становилось своего рода рабочей моделью для формирования предельно унифицированного, предельно оптимистического социального сознания. Поэтому охота за криптосимволикой , которой действительно было предостаточно, в официальном миропонимании носила характер необходимого общественного самоочищения. Но вопреки этой охоте, а отчасти и из-за нее, антагонистический разрыв между верхним, публичным, и нижним, независимо-индивидуальным, независимо-«кружковым» (или, говоря нынешним ироническим языком, «кухонным») пластами эстетического мышления , продолжал углубляться, что придавало советской художественной жизни тех лет особую сложность, трагическую напряженность и вместе с тем театрализованную причудливость» ${ }^{10}$ [1. С.212] . Написанная осенью в Мартышкино предметная композиция Уводской не имеет названия, и обнаруживает намерение автора по-своему интерпретировать обозначившуюся в трансформации жанра

10. Указ. соч. С.212 
тенденцию к расширению, обрастанию сопутствующими мотивами. Её натюрморт буквально распадается на глазах у зрителя. Вместо характерных для построения подобных натюрмортов аккуратно придвинутых к подоконникам столов с фронтально расставленными на них, продуманно сгруппированными элементами предметного ансамбля, здесь -направляемый сверху взгляд зрителя упирается в угол повернутого к нему стола с небрежно наброшенной, морщинящейся складками скатертью и рассыпанными на ней яблоками. При этом букеты осенних садовых цветов в стеклянных вазах и другие традиционно присутствующие в подобных композициях предметы решительно отставлены в сторону и теснятся по краям стола и у подоконника. Яблочный Спас, обозначающий поворот в природе, ассоциируется с поворотом в умонастроении автора, освободившегося от иллюзий и испытавшего облегчение. Возможно, в дальнейшем новые поиски исследователей увенчаются успехом и обнаружатся чудом уцелевшие письменные свидетельства, которые откроют нам важные подробности жизни и переживаний художницы, помогут уяснить связь образа и эпохи [14.P.257267]; откроют и помогут понять, что стояло за противопоставлением двух мотивов: яблока - этого многозначного, вечного символа и символического значения сопутствующего здесь ему изобразительного мотива - части небольшого окна с выцветшим, застиранным клочком занавески, за выражением двух настроений: радостного и просветленного чувства прозрения, неожиданно обретенной свободы и одновременно ясно осознаваемой реальности до предела сузившейся картины мира вовне.

Работа, которой мы завершаем представление натюрмортов Е.В.Уводской, инспирирована реакцией художницы на атрибуты репрезентативности официального и салонного типов этого жанра: обилие антикварной посуды, мелкой пластики, мебели, мотивы классической драпировки и пр. Все они присутствуют в предметной композиции художницы, но совершенно в другом амплуа. Основу натюрморта составляют украшенные «золотным шитьем» изделия из ткани. В золотистом мерцании её декора глаз едва различает отдельные предметы дорогих сервизов, миниатюрные фарфоровые фигурки, погруженные в складки материи. Небрежно разложенные и расставленные, теряющиеся в пестроте кое- как собранных кусков шитья посуда и статуэтки, воспринимаются вовсе не как те красивые предметы, которые составляют идеально построенный натюрморт. Предметы эти наделены чисто знаковыми функциями и находятся в знаковом пространстве художественной метафоры, скрывающей мысль об утрате духовных ценностей. Символ распредмечивается и символическое значение приобретает атмосфера, создаваемая языком живописи [11.С.146]. Эмоциональную окраску изображаемому придает колористическое решение, построенное на валёрных градациях и тонких цветовых переходах. 
Проникая в содержание произведений обоих художников, мы выясняем, что связь их творчества с эпохой осуществлялась в форме «ответа на вызов». Иконологический метод считывания культурных смыслов, разгадывания символов, помогает выявить в структуре этих произведений, их стилистике, семантике и символике утверждение другой реальности, создателями которой становятся творческие личности. Такое глубокое проникновение в мир художественного творчества, позволяет выявить разные пласты духовной реальности и получить более ясное представление о подлинной картине культурной жизни эпохи.

\section{ЛИТЕРАТУРА И ИСТОЧНИКИ:}

1. Соколов М.Н. Иконология и вопросы изучения советского искусства - к проблеме «скрытого символизма» // Стиль - Образ - Время. М.: НИИ РАХ, 1991

2. Panofsky E. Renaissance and Renascences in Western art: in 2 vols. Stockholm: Almquist and Wiksell, 1960. C.141-142

3. Панофски Эрвин IDEA. К истории понятия в терминах искусства от античности до классицизма. АХІОМА. Санкт-Петербург. 1999. C. $78,85,86$

4. Алпатов М. Итальянское искусство эпохи Данте и Джотто. М.,1939. C. 153

5. Малинина Т.Г. Художник Н.А. Протопопов и его семья. Опыт биографического исследования. С.94-110// Кабинет ученого. Научные статьи, публикации, эссе. М.: Прогресс-Традиция.. 2006

6. Выставка произведений художника Н.А.Протопопова. Каталог. Ленизо. 1951

7. Wilhelmi Chr, Handbuch der Symbole in der bildenden Kunst des 20 Jhs. Frankfurt - am - Main - Berlin, 1980

8. Дело учащейся Беляевой (Уводской) Е.В. См.:РГИА СПб. ВХУИАХ. Ф.789. Оп.12.1903г. Д.И - .96

9. Бурлюк Д. Воспоминания отца русского футуризма. С.27// Минувшее. Исторический альманах. 5. Copyright by Atheneum.1988. Paris

10. Барковская О.М. Одесское художественное училище. Хроника 1865 1940. С.133// «Вісник Одеського художнього музею».2.Одесса, 2015.

11. Boehm G. O obrazach i widzeniu. Antologia tekstow/ Red.D.Kolacka, tlum.Lukasiewicz, A.Pieczynska Sulik.-Krakow. 2014. S.146

12. Gray, Camilla (Gray, Camilla).The Russian contribution to Modern painting Burlington Magasine, 05/1960 | 686 | 102 Pages: 204-211

13. Wilson, Sarah. "La Beauté Révolutionnaire"? Réalisme Socialiste and French Painting 1935-1954.Oxford Art Journal, Volume 3, Issue 2, O

14. Damisch, Hubert. Eight Theses For (or Against?) A Semiology of Painting. Oxford Art Journal, Volume 28, Issue 2, June 2005, Pages 257-267 
15. Azatyan, Vardan. Ernst Gombrich's Politics of Art History: Exile, Cold War and The Story of Art. Oxford Art Journal, Volume 33, Issue 2, June 2010, Pages 127-141

16. Barnaby, Haran. Tractor Factory Facts: Margaret Bourke-White's Eyes on Russia and the Romance of Industry in the Five-Year Plan. Oxford Art Journal, Volume 38, Issue 1, March 2015, Pages 73-93

17. Хузина Татьяна Евгеньевна. Предметный мир в советской живописи 1930-х гг:: семантический анализ: диссертация ...кандидата искусствоведения : 17.00.09. / Хузина Татьяна Евгеньевна; [Место защиты: Санкт-Петербургский государственный академический институт живописи, скульптуры и архитектуры имени И. Е. Репина при Российской академии художеств ].- Санкт-Петербург, 2009.- 177 с.: ил. РГБ ОД, 61 10-17/38 